\title{
Prevalence and Serological Detection of Spiroplasma citri, a Cause of Citrus Stubborn Disease in Southern Punjab, Pakistan
}

\author{
Ummad ud Din Umar ${ }^{1}$, Syed Atif Hasan Naqvi ${ }^{1 *}$, Ishfaq Ahmed ${ }^{1}$, Ateeq ur Rehman ${ }^{1}$, Muhammad Asif \\ Zulfiqar $^{2}$,Sibghat Ullah ${ }^{3}$, Shah Pasand ${ }^{4}, Z_{\text {Zhri Khan }}^{3}$ and Abdur Rehman
}

${ }^{1}$ Department of Plant Pathology, BZU, Multan, 60800, Pakistan; ${ }^{2} P A R C$, Research and Training Station, BZU, Multan. ${ }^{3}$ PARC, Horticulture Research Institute, Khuzdar, ${ }^{4}$ PARC, Social Sciences Research Institute, Quetta, ${ }^{5}$ Plant Protection Department, College of Food and Agriculture Sciences, King Saud University, Riyadh, Saudi Arabia.

Abstract | Spiroplasma citri, a fastidious pathogen, is considered as the main cause of Citrus little leaf disease
(Citrus stubborn disease) which is not only responsible for the low citrus production in terms of quality and
quantity but also moving the citrus industry to down fall in citrus growing areas throughout the world.
Current research was organized to study the distribution of disease using the serological based detection
methods by conducting a comprehensive survey in various districts of Southern Punjab. The results of the
survey and serology of CSD showed that this destructive disease which causes symptoms mostly similar to
citrus greening is present in all areas of South Punjab. Layyah, and Multan showed maximum incidence of
CSD with "11.66" and “5.66\%" respectively while least incidence was observed in District Bhakkar (03\%) and
District Khanewal with (02\%) incidence. Sweet orange and grape fruit depicted themselves as susceptible ones
showing maximum disease with "18.33" and minimum "02\%” respectively. Kinnow mandarin and feutral's
early appeared as resistant cultivars against CSD infection in all the surveyed areas. Small acorn shaped,
lopsided fruit and leaves with shortened internodes were appeared to be characteristic disease symptoms in
Citrus stands of Southern Punjab.
Received | June 01, 2020; Accepted | July 27,2020; Published | October 06, 2020
"Correspondence | Syed Atif Hasan Naqvi, Department of Plant Pathology, BZU, Multan, 60800, Pakistan; Email: atifhasanshah@hotmail.
com
Citation | Umar, U.D.U., S.A.H. Naqvi, I. Ahmed, A. Rehman, M.A. Zulfiqar, S. Ullah, S. Pasand, Z. Khan and A. Rehman. 2020. Prevalence
and serological detection of Spiroplasma citri, a cause of citrus stubborn disease in southern Punjab, Pakistan. Pakistan Journal of Agricultural
Research, 33(4): 748-753.
DOI | http://dx.doi.org/10.17582/journal.pjar/2020/33.4.748.753
Keywords | Occurrence, Oranges, ELISA, Fastidious, Wall less bacteria

\section{Introduction}

$\mathrm{T}$ axonomically citrus belongs to the family "Rutaceae" and considered as important genus from kingdom plantae which originated from South of China and Himalayan countries. Being a vital fruit crop, which is planted in most of the countries around the globe its high yield grants a big profit and economic reward to its growers. Citrus possesses a lot of necessary nutrient compounds such as fibrous compounds, sugary compounds, Vitamin $\mathrm{B}_{2}$,
Vitamin $\mathrm{B}_{6}$, Phosphorus, and other phytochemical compounds (Abu-Zeid et al., 1988; Bove et al., 1983). Globally, Pakistan ranks $10^{\text {th }}$ among major citrus producing countries all around the globe in terms of quantity and quality. Among the four provinces of Pakistan, Punjab contributes $94 \%$ to Citrus production followed by Khyber Pakhtunkhwa with 3\%, Sindh $2.7 \%$ and Baluchistan with 1.7\%, respectively out of total production. Climatic conditions of Punjab province are highly conducive for this crop and making it as top yielding province 
in Pakistan especially in its regions like, Sahiwal, Sargodha, Toba Tak Singh and Layyah. As for as export of this fruit commodity is concerned, kinnow mandrin gave its maximum share with $70 \%$ enabling Pakistani $5^{\text {th }}$ largest country in terms of citrus export. (Annonymous, 2018). There are a lot of serious issues in citrus's agroecosystem bringing citrus towards huge loss of production such as infectious diseases (fungal, viral, viroid's and nematode diseases) insect infestations, and non-infectious problems i.e., various nutrient deficiencies and environmental stresses). Citrus stubborn diseases are a most damaging one among all the infectious diseases under semiarid conditions where Spiroplasma citri appears destructively in many world's countries (Bradbury, 1991). Literature has proved that no favor is being provided by low temperature to CSD pathogen and vector, which decides that the disease possesses summer prevalence (Bradbury, 1991). S. citri thrives best in range of high temperature $\left(28-32^{\circ} \mathrm{C}\right)$ and may produce non-conspicuous symptoms at cool temperature. Bove et al. (2002) explained the huge perceived impairment due to stubborn in Syria. The series of experiments conducted on same plants each year has proven more mortality at higher temperature $\left(>30^{\circ} \mathrm{C}\right)$ as compared to low temperature wherein plants remain asymptomatic (Boonham et al., 2014). The diseases is transmitted by its vector from infected to healthy plants in citrus groves (Gumpf and Calavan, 1981), while $S$. citri can be transmitted to horse reddish experimentally (Sheta et al., 2004). To the extent of current day literature on CSD, no strain indication has been reported of $S$. citri. CSD was first ever observed and reported from California, USA upon Navel trees of oranges (Wisler et al., 1992). A characteristic symptom of acorn-morph-formation on infected citrus fruit leads towards the nomination of disease as "acorned disease." Literature has also reported the same disease from Palestine in 1930 as "Little Leaf Disease" with the proofs of transmission possession of CSD as explained by (Fawcett et al., 1944).

Graft inoculation on indicator plants has been used to detect $S$. citri, on madame vinous placed at 32 to $27^{\circ} \mathrm{C}$ day and night temperature respectively (Bove, 1988). Grapefruit, tangelo, sexton and Marsh are some important indicators plants used to detect CSD pathogen where midrib of the leaf has been reported the region where maximum amount of titter can be detected. Symptomatic trees can help to culture
S. citri with best seeding material having numerous abortion extent while fruit axis with peduncle end or mottled seasonal leaves gathered in October (Bove, 1988). Since cutlturability of organism declared antisera are easy to grasp. ELISA is the technique applied to detect and identify $S$. citri from infected plants and insect extract (Clark and Adam, 1977) while rapid detection can also be done using latex agglutination technique (Fletcher and Slack, 1986). Little leaf disease trees also develop acorn fashioned and loped fruits having thin skin on stylar area of fruit leading towards premature breakdown of acorn fashioned fruit. CSD infected fruit appears often greenish to yellowish, bitter/sour tasted/flavored and generally show blue color from inside. Leaves appear erected, trees show shortened internodes and bunchy formation of leaves. Small leaves appear mottled just similar to zinc deficiency symptoms as compared to healthy leaves. Furthermore, CSD infected citrus shrubs produces poor foliage and fruit develops abnormally (Bove et al., 1974). Other symptoms are severe dwarfing of younger trees, short internodal distance and thick shrubbery with cupped, alternative Chlorotic patterned and thickened leaves. Considering the aforementioned facts present research intended to determine the prevalence of the Spiroplasma citri through its serological based detection in the noncore area of Southern Punjab.

\section{Materials and Methods}

\section{Study sites}

The research was performed at Department of Plant Pathology, Faculty of Agricultural Sciences and Technology, Bahauddin Zakariya University Multan.

\section{Investigation for the assortment of CSD affected specimen} The disease was visualized with characteristic symptoms including bunchy formed growth with reduced internodes usually erect leaves similar to zinc deficiency, acorn and lopsided shaped fruits. Investigation about CSD in different regions of Punjab including Multan, Khanewal, Layyah and Bhakkar was performed and symptomatic specimens of CSD were gathered. The samples were placed in plastic zipper bags in ice box.

\section{Disease incidenceloccurrence and cultivar vulnerability}

Disease occurrence for all the regions was computed by the formula for disease incidence and the cultivar vulnerability was also evaluated for CSD. 


\section{Disease incidence $\%=\frac{\text { Infected Plants }}{\text { Total } \text { Plants }} \times 100$}

\section{Serological detection of CSD}

Clark and Adams in 1977 utilized binary antibody sandwiched (BAS) ELISA for the recognition of $S$. citri. where Agdia Inc. USA made the antibodies available. Microplate was glazed with coating buffer holding 100ul of arrested antibody thereafter microplate was over nightly incubated at $4^{\circ} \mathrm{C}$. Phosphate buffer saline tween PBST $\mathrm{pH} 7.4$ (washing purpose buffer) was utilized to rinse the plate thrice. Antigen or infected plant mass was taken out in $5 \mathrm{ml}$ abstraction/ extraction buffer $7.4 \mathrm{pH}$ from $500 \mathrm{mg}$ leaf tissues and individual well of microplate was poured with $0.1 \mathrm{ml}$ extract. The incubation was provided overnight at $4^{\circ} \mathrm{C}$ and the microtiter plate was again rinsed using washing buffer 5 to 6 times. Then microtiter plate was glazed with conjugate/ coupled antibody in conjugate/ coupling buffer and the micro plate was placed at ambient temperature for incubation of $2 \mathrm{hrs}$. Thereafter the plate's washing was done 4-5 times with PBST. Substrate buffer was synthesized by dissolving $1 \mathrm{mg} / \mathrm{ml} \mathrm{pNpp}$ tablet and the microplate was glazed 25 minutes at ambient temperature. The absorbance was gauged at $405 \mathrm{~nm}$ on ELISA plate observer (Biotek. Inc) U.S.A.

\section{Results and Discussion}

Occurrence of Spiroplasma citri in various regions

Citrus stubborn disease (CSD) was founded in all inspected regions of the Punjab. Extreme disease occurrence of CSD was pragmatic in Layyah (11.66\%) followed by Multan (5.660\%), Bhakkar (3.33\%) and District Khanewal with (02\%) occurrence. Investigation outcomes exposed highest disease incidence in Layyah and minimum occurrence in District Khanewal (Figure 1).

\section{Cultivar vulnerability in the direction of citrus little leaf} disease

Outcomes of cultivar's vulnerability exposed that maximum value of CSD was present on Citrus sinensis (18.33\%) and least was evident on Citrus paradisi (02\%) while feutral's early and kinnow exposed less disease infestation. (Figure 2).

\section{Serological proof of identity of CSD}

The ELISA outcomes exposed that specimens from grapefruit and sweet orange (Citrus sinensis) provided positive reply in the direction of the serological finding of CSD. While kinnow, feutral's early and mandarin exposed colorless means negative. The Maximum range of titer was evaluated in sweet orange (Citrus sinensis) (0.147-0.258) and in grapefruit (Citrus paradisi) (0.171-0.172) (Table 1, Figure 3).

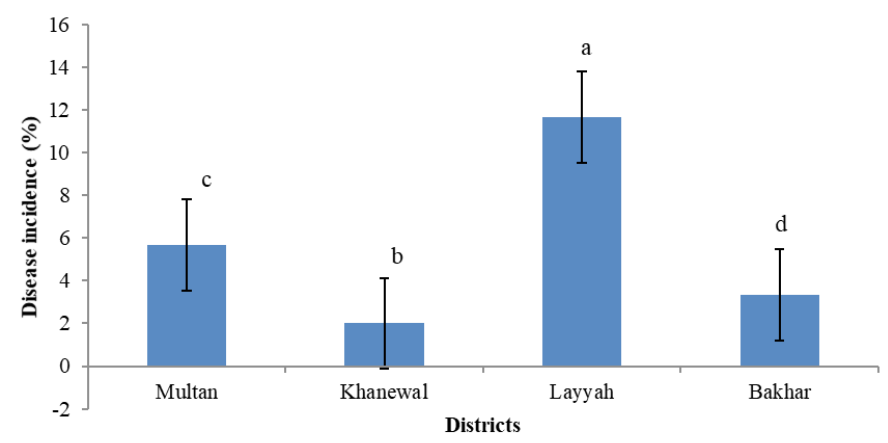

Figure 1: Disease incidence \% in different districts of Punjab.

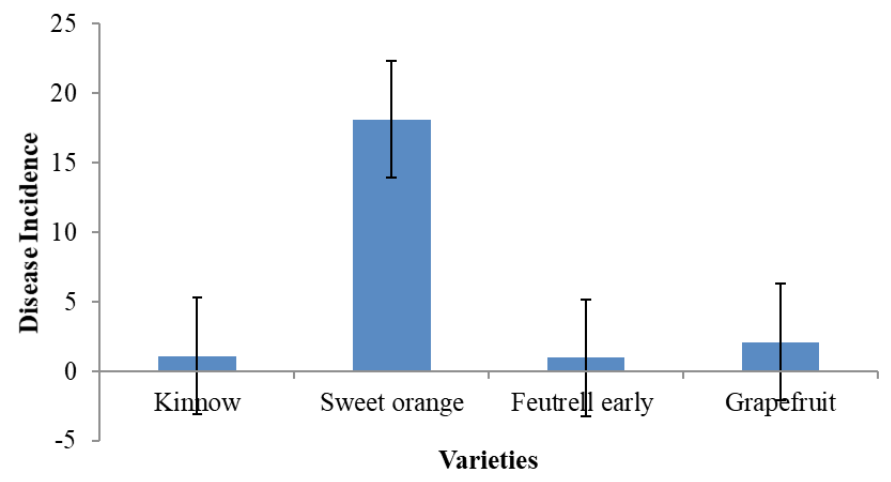

Figure 2: Cultivar susceptibility of CSD.

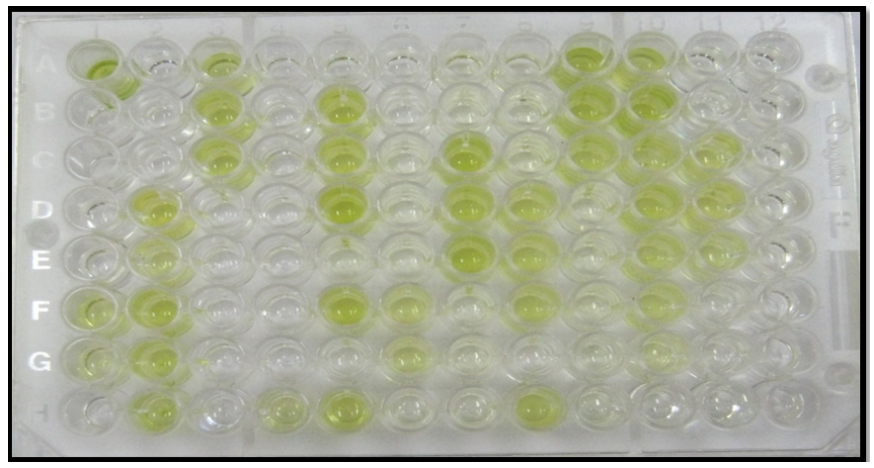

Figure 3: Serological detection of Spiroplasma citri (Lane 1: Positive sample in well one, negative sample in well 2, Lane B: healthy sample 2 wells).

Citrus is very crucial fruiting crop for world's countries. Top quality citrus from Pakistan is a best cause of foreign exchange. Up till now, Citrus of Pakistan is hampered by a variety of pathosystems which not only affecting quantity but also quality of Citrus fruit and tree. Acorny citrus disease (ACD) etiolated by Spiropalsma citri oozing out as a major hurdle for Citrus growing world's countries. Low temperature climates discouraging the pathogen as 
well as its vector which making it obvious that CSD is subtropical situation lover disease.

Table 1: Reaction of citrus tissues in CSD-ELISA tests.

$\begin{array}{lll}\text { Source Plant } & \text { Reaction } & \text { ELISA Value }\left(\mathbf{A}_{\mathbf{4 0 5}} \text { n.m.) }\right. \\ \text { Kinnow Mandrin } & \text { Negative } & 0.013-0.017 \\ \text { Sweet orange } & \text { Positive } & 0.147-0.258 \\ \text { Feutral's early } & \text { Negative } & 0.031-0.035 \\ \text { Grape fruit } & \text { Positive } & 0.171-0.172 \\ \text { Positive test sample } & \text { Positive } & 0.172-0.257 \\ \text { Negative sample } & \text { Negative } & 0.027 \\ \text { Healthy sample } & \text { Negative } & 0.016\end{array}$

In present research we described that CSD infection in citrus groves of numerous regions of the South Punjab to determine the prevalence and spread of the CSD through serological and molecular methods. We determined that CSD identified in all investigated regions of Punjab. The collected samples were tested with ELISA and the symptoms were correlated with the results. Maximum disease incidence was recorded in Layyah (11.66\%) trailed by Multan (5.66\%), Bhakkar (03\%) and District Khanewal (02\%). Maximum and minimum threshold of disease was founded on sweet orange (18.33\%) and grapefruit (2\%) while no evidence of disease infestation was recorded on feutral's early and kinnow mandrin. ELISA results leaded us towards decision of positive reaction formation from sweet orange and grapefruit samples while negative reaction formation from feutral's early and kinnow samples while these results are also in line with the Bove et al., 1984 who described ELISA as an important technique to detect CSD. Adding to this, outcomes in culturing/ rearing and CSD detection through ELISA has stood much promising in Syria where thirty-eight citrus shrub samples exposed positively colored outcome by methodology of culturing and 38 trees samples founded colorful by ELISA (means positive) out of forty-seven verified CSD infected trees.

To diagnose CSD in the field, most promising and authentic symptoms are fruit symptoms which are more useful and characteristic. Few cases provide evidence of formation of acorned, premature, irregular, and loped fruits on the shrub, thin skin of fruit particularly at stylar helps in breakdown of acorny fruit. Diseased shrub produces acorny and loped fruits which remain greenish to yellowish with false taste as similar symptoms has been observed by
Mello et al. (2008). Moreover, Distribution of S. citri exposed graft experimentation as unreliable in plants with low pathogen titer appeared at low temperature as discussed by Gumpf and Calavan, 1981. For this reason, we observed in many years that hot summer season is more effective for inoculum development, collection and sampling for transmission experiments and detection of $S$. citri. as $S$. citri was mostly detected from the samples during summer. Hot temperature in greenhouse is essential for symptoms expression in control environments. Day temperature should be in range of $\left(32-38^{\circ} \mathrm{C}\right)$ while night temperature should not be less than $27^{\circ} \mathrm{C}$. Temperature should not exceed $40^{\circ} \mathrm{C}$ in any length of time. The epidemiological aspects of CSD are complicated as discussed by researchers conducting their research on wall-less millicutes. Pathogen possesses a with wide range of host including weeds and commercialized crops. It has also a wide range of leaf hopper vectors. All these factors could stimulate the extent of impact of CSD in grooves.

\section{Conclusions and Recommendations}

S. citri has the capability to raise economic losses by impacting various host crops which ultimately leads to enhancement of grower's concern. Insect vector elimination methods are crucial for preventing pathogen spread.

\section{Acknowledgments}

The authors are highly grateful to $\mathrm{S}$. Anwar Rizvi, $\mathrm{Ph}$. D. Ex-Senior Staff Officer, USDA-APHIS-PPQPHP, Former Area Director - South America, USA for the provision of logistic support for the research work. Special thanks are also due to Agdia, Inc. 52642 County Road 1, Elkhart, IN 46514, USA (info@ agdia.com) for the provision of Antibodies for the detection of Spiroplasma citri for the current research work.

\section{Novelty Statement}

Novelty of the research is that it is the first study on the devastating pathogen "Spiroplasma citri" of citrus causing enormous losses to the grooves showing the current status, etiology, symptomatology, cultivar susceptibility and serological detection of the pathogen in the non-core of the Southern Punjab, Pakistan. 
Author's Contribution

Ummad ud Din Umar, Syed Atif Hasan Naqvi and Ateeq ur Rehman conceived the idea, experiments were performed by Ishfaq Ahmed, Syed Atif Hasan Naqvi and Abdur Rehman. Statistical analysis was performed by Syed Atif Hasan Naqvi, Sibghat Ullah and Shah Pasand while references were managed by Muhammad Asif, Zulfiqar and Zehri Khan.

\section{Funding}

The research was funded by the Office of Research Innovation and Commercialization, Bahauddin Zakariya University, Multan, 60800, Pakistan.

\section{Conflict of interest}

The authors have declared no conflict of interest.

\section{References}

Abu-Zeid, A., A. Kishtah and E.M. Khalil. 1988. Isolation and culturing of Spiroplasmacitri associated with stubborn disease of citrus in Egypt. J. Phytopathol., 20: 139-140.

Anonymous. 2018. Pakistan Statistical Year Book. Federal Bur. Stat., Statistical Division. Karachi. Pakistan.

Boonham, N., J. Kreuze, S. Winter, R. van der Vlugt, J. Bergervoet, J. Tomlinson and R. Mumford. 2014. Methods in virus diagnostics: From ELISA to next generation sequencing. Virus Res., 186: 20-31. https://doi.org/10.1016/j. virusres.2013.12.007

Bové, J.M., E.C. Calavan, S.P. Capoor, R.E. Cortez and E. Schwarz. 1974. Influence of temperature on symptoms of California stubborn, South Africa greening, India citrus decline and Philippines leaf mottling diseases. In: Conf. Int. Org. Citrus Virol., L.G. Weathers and M. Cohen, eds., Richmond, V.A. pp. 12-15.

Bové, J.M., J. Renaudin, X. Foissac, P. Gaurivaud, P. Carle, F. Laigret, C. Saillard and M. Garnier. 2002. Spiroplasmacitri from functional genomics to genomics. In: Proc. $15^{\text {th }}$ Conf. Int. Organ. Citrus Virol. N. Duran-Villa, R. G. Milne, and J. V. da Graça, eds. IOCV, Riverside, CA. pp. 278-287.

Bové, J.M., R.E. Whitcomb and R.E. McCoy. 1983. Culture techniques forspiroplasmas from plants. In: Methods in Mycoplasmology, J.G. Tully and S. Razin, eds. Academic Press, Inc,
N.Y. pp. 225-234. https://doi.org/10.1016/ B978-0-12-583802-3.50032-X

Bové,J.M., 1988. Epidemiology of Spiroplasmacitri in the old world. In: Proc. $10^{\text {th }}$ Conf. IOCV, Riverside, IOCV. pp. 295-299.

Bradbury, J.F., 1991. Spiroplasmacitri. CMI Descriptions of Fungi and Bacteria No. 1046. CAB International, Wallingford, UK.

Clark, M.F. and A.N. Adams. 1977. Characteristics of the microplate method of enzyme- linked immunosorbent assay for the detection of plant viruses. J. Gen. Virol. 34: 475-483. https://doi. org/10.1099/0022-1317-34-3-475

Fawcett, H.S., J.C. Perry and J.C. Johnson.1944. The stubborn disease of citrus. Calif.: Citrogr., 29: $140-147$.

Fletcher,J.and S.A.Slack. 1986. Latex agglutination as a rapid detection assay for Spiroplasmacitri. Plant Dis., 70: 754-756. https://doi. org/10.1094/PD-70-754

GoP. 2015. Agriculture statistics of Pakistan. Ministry of food, agriculture and livestock. Economic, trade and investment wing. Islamabad, Pakistan.

Gumpf, D.J. and E.C. Calavan. 1981. Stubborn disease of citrus. In: Maramorosch, K. and Raychaudhuri, S.P., eds. Mycoplasma diseases of trees and shrubs. New York, Academic Press. pp. 97-134. https://doi.org/10.1016/B978-012-470220-2.50008-0

Mello, A.F.S., R.K. Yokomi, U. Melcher, J.C. Chen, A.C. Wayadande and J. Fletcher. 2008. Genetic diversity of Spiroplasmacitri strains from different regions, hosts, and isolation dates. Phytopathology. 98: 960-968. https:// doi.org/10.1094/PHYTO-98-9-0960

Oldfield, G.N., D.A. Sullivan and E.C. Calavan. 1984. Inoculativity of leafhopper vectors of stubborn disease in California. In: Proc. $9^{\text {th }}$ Conf. Int. Organ. Citrus Virol. S.M. Garnsey, L.W. Timmer and J.A. Dodds, eds. IOCV, Riverside, CA.pp. 125-130.

Reichert, I., 1930. Diseases, new to citrus, found in Palestine. Phytopathol., 20: 999-1002.

Sheta, E., S. Salem, A.M. Abou-Zeid, M. Osman, M.A. Shafik and A. El-Hawari. 2004. Development of a citrus certification program in Egypt. Proc. 15 $5^{\text {th }}$ Conf. Int. Org. Citrus Virol. (IOCV), Riverside, 3-6 November 2004, pp. 321-329.

Whiteside, J.O., S.M. Garney and L.W. Timmer. 
1988. Compendium of citrus diseases. APS Press, St. Paul. pp. 80.

Wisler, G.C., S.M. Garnsey, L.G. Brown and C.L. Schoulties. 1992. Manual for introduction of citrus germplasm into Florida. Division of Plant Industry P.O. Box 147100 Gainesville, FL 32614-7100. 